\title{
Sleeping Habits of Primary School Children and Affecting Factors
}

\section{Illkokul Çağı Çocuklarında Uyku Alıșkanlıkları ve Etkileyen Faktörler}

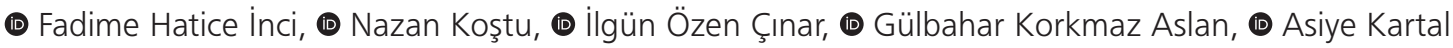 \\ Pamukkale University Faculty of Health Sciences, Department of Public Health Nursing, Denizli, Turkey
}

\begin{abstract}
Objective: The present study was conducted to investigate the sleep habits of primary school children and identify factors affecting it.

Materials and Methods: This cross-sectional, descriptive study comprised 1876 school-aged children (ages 6-11 years). The Sociodemographic Characteristics questionnaire and Children's Sleep Habits questionnaire were used as data-gathering tools. Before the study was started, ethical approval was obtained from the ethics committee. All statistical data were analyzed using the SPSS program. In descriptive statistics, mean, standard deviation, frequency, and percentages were used. Sleep habits and related variables were analyzed using the student's t-test and One-Way ANOVA test. Statistical significance was determined as $\mathrm{p}<0.05$.

Results: The study comprised 1876 students, with ages ranging from 6 to 11 years (mean $8.52 \pm 1.21$ years). Of these, $51.5 \%(n=966)$ were girls, $48.5 \%(n=910)$ were boys, and $71.2 \%$ had a sleep disorder. The mean bedtime was 10:01 p.m. $\pm 0: 49$ min, the mean wake-up time was 07:35 a.m. $\pm 0: 55 \mathrm{~min}$, and the mean sleep duration was $9.33 \pm 1.13$ hours. Significant differences were observed among the participants sleeping habits in terms of variables, such as parental education level, family structure, family income, chronic diseases, computer game addiction, and dietary pattern $(\mathrm{p}<0.05)$.

Conclusion: It is recommended that school nurses be more careful when evaluating the sleep characteristics of school-aged children. Moreover, school nurses should inform parents and children of any sleep problems. Keywords: Affecting factors, sleep habits, primary school children
\end{abstract}

Öz

Amaç: Bu çalışma ilkokul çağı çocuklarında uyku alışkanlıklarını ve etkileyen faktörleri belirlemek için yapılmıştır.

Gereç ve Yöntem: Tanımlayıcı ve kesitsel bir çalışmadır. Örneklem okul çağındaki 6-11 yaş 1876 çocuktan oluşmaktadır. Veri toplama formu olarak Sosyodemografik Özellikler formu ve Çocuk Uyku Alışkanlıkları anketi kullanılmıştır. Çalışma başlamadan önce etik kuruldan etik onay alındı. Tüm istatistiksel veriler SPSS programı kullanılarak analiz edildi. Tanımlayıcı istatistiklerde ortalama, standart sapma, sıklık ve yüzde kullanıldı. Uyku alışkanlıkları ve ilişkili değişkenler student t-testi ve OneWay ANOVA testi ile analiz edildi. İstatistiksel anlamlılık $p<0,05$ olarak belirlendi.

Bulgular: Çalışmaya 1876 öğrenci dahil edildi. Çocukların yaşı 6-11

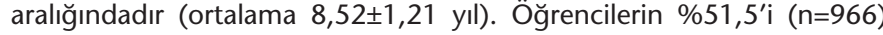
kadın,\%48,5'i (n=910) erkek ve \%71,2'sinde uyku bozukluğu vardı. Ortalama yatma vakti saat 22:01 $\pm 0: 49 \mathrm{dk}$, ortalama uyanma süresi 07:35 $\pm 0: 55 \mathrm{dk}$, ortalama uyku süresi $9,33 \pm 1,13$ saat idi. Ebeveyn eğitim düzeyi, aile yapısı, aile geliri, kronik hastalıklar, bilgisayar oyunu oynama ve beslenme düzeni gibi değişkenler açısından çocukların uyku alışkanlıkları puan ortalamaları arasında anlamlı farklııklar vardı ( $\mathrm{p}$ $<0,05)$.

Sonuç: Okul hemşirelerinin, okul çağındaki çocukların uyku özelliklerini değerlendirirken daha dikkatli ve sorgulayıcı olmaları önerilebilir. Okul hemşireleri ebeveynleri ve çocukları uyku sorunları hakkında bilgilendirmelidir.

Anahtar Kelimeler: Etkileyen faktörler, uyku alışkanlıkları, ilkokul çocukları

\section{Introduction}

Sleep is essential to good health. Sleep significantly affects the quality of life and well-being of an individual. A good sleep plays a key role in disease resistance, injury prevention, clarity of thought, and stability of mood (1). Twenty-five percent of children experience sleep problems during childhood, and night waking/bedtime resistance is reported most commonly $(2,3)$.

Healthy sleep habits for children are important. However, some factors may adversely affect children's sleep habits. In studies conducted on children's sleep habits, the following factors have been reported to affect their sleep health: obesity $(4,5)$, dietary habits (6-8), consumption of junk food and high-calorie drinks

Address for Correspondence/Yazışma Adresi: Fadime Hatice İnci PhD, Pamukkale University Faculty of Health Sciences, Department of Public Health Nursing, Denizli, Turkey Phone: +902582964352 E-mail: hemel@pau.edu.tr ORCID-ID: orcid.org/0000-0003-0893-0010

Received/Geliş Tarihi: 01.10.2019 Accepted/Kabul Tarihi: 06.01.2020

${ }^{\circ}$ Copyright 2020 by Turkish Sleep Medicine Society / Journal of Turkish Sleep Medicine published by Galenos Publishing House. 
(9), family factors (10-14), sleep routines, time spent watching television or using computer or smart phones (15-19), and the presence of a chronic disease (20-22).

It is well known that sleep has a significant impact on the growth and development of children. The average sleep time for school-age children is recommended to be more than 10 hours $(23,24)$. The American Academy of Pediatrics recommends that children 6 to 12 years of age should sleep 9 to 12 hours per 24 hours on a regular basis to promote optimal health (25). Inadequate sleep health is adversely affected. In order to prevent the adverse health effects of sleep problems on children, they should be provided with opportunities to sleep and rest well. Inadequate sleep is an important public health problem affecting children's health seriously (26). For this reason, it is important to determine the sleeping habits in children, to define the sleep problems well and to determine the factors affecting the sleep health and to make appropriate interventions.

The aim of the present study was to assess the sleep habits of schoolchildren and factors affecting of the sleep habits of school children in Turkish population.

\section{Materials and Methods}

The study was designed as a cross-sectional one. The study population of this cross-sectional research covered 46 primary schools. Four primary schools were selected by the simple random technique. The sample consisted of 1876 students (ages 6-11) in these schools.

Data collection was performed during March 2015 and June 2015. The Sociodemographic Characteristics questionnaire and Dietary Pattern index (DPI) were filled in by students. Body Mass index (BMI) was measured by the researchers. The Children's Sleep Habits questionnaire (CSHQ) was filled in by the parents of students.

The Sociodemographic Characteristics questionnaire, BMI, DPI and the CSHQ were used as data gathering instruments.

\section{The Sociodemographic Characteristics Questionnaire}

This form was prepared by the researchers and included questions to gather data about sociodemographic characteristics of the children such as, age, gender, education level of parents, mothers' employment status, family income, playing computer games and watching television.

\section{Body Mass Index}

Anthropometrics were measured by the researchers following the standard procedures. BMl was defined as weight in kilograms divided by height in meters squared. Children and adolescents who measure between the $85^{\text {th }}$ to $<95^{\text {th }}$ percentiles are considered overweight, and those at the $\geq 95^{\text {th }}$ percentile are considered obese (27).

\section{Dietary Pattern Index}

The DPI developed by Demirezen and Caşansu (28) includes 6 items questioning the respondents' eating habits (e.g., eating vegetables, fruits, fatty and sugary foods and drinking tea, coffee, salt consumption). The responses are measured using a 4-point Likert-type scale ( $0=$ never to $4=$ always). One of the items is reverse scored. The total score ranges from 0 to 24 , with higher scores representing unhealthier eating habits. Total score was categorized as no risk (0 points), low risk (1-6 points), intermediate risk (7-12 points), high risk (13-18 points), very high risk (19-24 points). The internal consistency of the scale is 0.68 .

\section{The Children's Sleep Habits Questionnaire}

The CSHQ was developed by Owens et al (29). The CSHQ is a retrospective, 41 -item parent questionnaire that has been used in a number of studies to examine sleep behavior in young children. The CSHQ includes items relating to a number of key sleep domains that encompass the major presenting clinical sleep complaints in this age group: bedtime behavior and sleep onset, sleep duration, anxiety around sleep, behavior occurring during sleep and night waking, sleep-disordered breathing, parasomnias, and morning waking/daytime sleepiness. Parents are asked to recall sleep behaviors occurring over a "typical" recent week. Items are rated on a three-point scale: (i) "usually" if the sleep behavior occurred five to seven times/week; (ii) "sometimes" for two to four times/week; and (iii) "rarely" for zero to one time/week. Some items are reversed in order to consistently make a higher score indicative of more disturbed sleep. A total score of over 41 indicates sleep problem. The internal consistency of the scale is 0.68-0.78 (29). The index was adapted into Turkish by Perdahlı Fiş et al. (30) The internal consistency of the Turkish version is 0.78 . In the present study, the internal consistency of the Turkish version of the scale is 0.61 .

\section{Human Subjects Approval Statement}

The study was approved by the Pamukkale University Ethics Committee (approval number: 60116787-020/3517). Ethical permissions were obtained from the Pamukkale University Ethics Committee, and provincial Directorate of National Education. Written consent was obtained from the parents and children by sending a letter explaining the aim and the procedures of the study, and a guarantee was given that the gathered data would not be used other than the aim of the study (they were ensured that the study data would be used within the scope of the study and would not be disclosed to third parties). All procedures were performed in accordance with the Declaration of Helsinki.

\section{Statistical Analysis}

The data were analyzed with the IBM Predictive Analytics SoftWare Statistical Product and Service Solutions version 22.0 (31). P values of $<0.05$ were considered statistically significant. Frequencies and percentages were used to describe the descriptive data and the characteristics of the primary school children. The data were analyzed using the Independent samples t-test and One-Way ANOVA test.

\section{Results}

Sleep habits of the participating primary school children are shown in Table 1. The mean bedtime was 10:01 p.m. $\pm 0: 49$ min., the mean wake up time was 07:35 a.m. $\pm 0: 55$ min., the 
mean sleep duration was $9.33 \pm 1.13$ hours. The mean CSHQ score was $45.99 \pm 7.36$.

The study included 1876 students. The age of the children ranged from 6 to 12 years (mean $8.52 \pm 1.21$ ). Of the students who participated in the study, $51.5 \%$ were girls, $38.1 \%$ had primary school graduate mothers, $32.6 \%$ had primary school graduate fathers, $47.5 \%$ had mothers working at a paid job, $8.4 \%$ had a chronic disease, and $62.2 \%$ had families with moderate income.

There were statistically significant differences between the scores obtained from the CSHQ in terms of the variables such as the maternal educational level, paternal educational level, family structure, family income, chronic diseases, playing computer games and dietary pattern. No relationship was found between sleep problems and the variables such as age, gender, mother's employment, BMI, watching television (Table 2).

\section{Discussion}

The present study provides information on the sleep habits of Turkish children who participated in the study. The children's sleep habits were assessed in terms of bedtime, wake up time, sleep duration and CSHQ scores.

In Amschler and McKenzie's study, the bedtime of the children was determined to range between 9:00 p.m. and 9:30 p.m. (1). In other studies, the bedtime was reported as 10:00 p.m. or later (32-34) In the present study, similar to other studies, the mean bedtime of the participating, students was 10:00 p.m. While the mean wake up time was 7:51 a.m. in Canet's study and 7:00 a.m. in Bharti et al. (35) study, it was before 8 a.m. in Koçoğlu et al. study $(32,33,35)$. On the other hand, in Amschler and McKenzie's study, the majority of the students woke up after 7:00 a.m (1). In the present study, the mean wake time was 7:35 a.m. which was consistent with the findings in the literature.

Given sleep duration, children in the 5-10 age group are categorized into 3 groups: normal sleepers $(\geq 10 \mathrm{~h})$, short sleepers $(8-9$ h) and shortest sleepers $(<8$ h) (23). The mean sleep duration of the students was 9.26 hours in Canet's study, 8.30 hours in Firouzi et al. (34) study, 8.77 hours in Bharti et al. (35) study, 9.20 hours in Li et al. (37) study and 8.42 hours in Park's study (32,34-37). In the present study, the mean sleep time of the students whose mean age was 8.52 years was 9.33 hours which was consistent with the findings of Canet's and Li et al. (37) studies (32). The mean sleep time of the students in the present study indicates that they were normal sleepers.

Studies show that sleep problems are a common health problem among students $(1,32,38)$. In Surani et al. (39) study,

\begin{tabular}{|l|l|l|}
\hline Table 1. Sleep habits of primary school children \\
\hline Variables & Mean & Standard deviation \\
\hline Bedtime (pm) & $10: 01$ & $0: 49$ \\
\hline Wake up time (am) & $7: 35$ & $0: 55$ \\
\hline Sleep duration (hours) & 9.33 & 1.15 \\
\hline CSHQ $^{*}$ & 45.99 & 7.36 \\
\hline${ }^{*}$ CSHQ: The Children's Sleep Habits Questionnaire \\
\hline
\end{tabular}

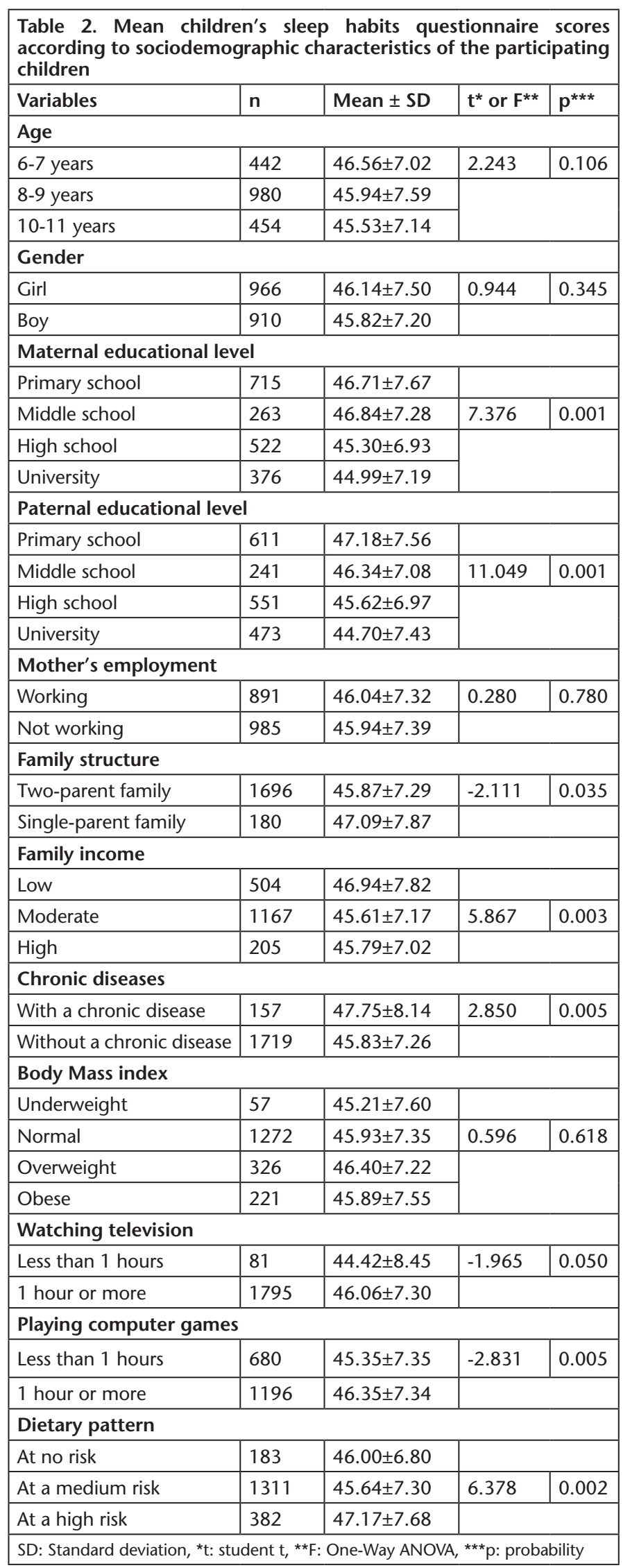


while the overall mean score for the CSHQ was 44.09 for the elementary school students and 44.18 for the middle school students, it ranged between 49.3 and 54.9 in Firouzi et al. (34) study. In the present study, the mean score the participating students obtained from the CSHQ was 45.99. Considering that the cut-off point of the scale was 41 , it can be said that the students had sleep problems. Their sleep patterns and sleep habits are distorted due to irregular sleep hours on school days, changes in sleep hours and spending more time in front of a computer and television on weekends (32).

This research, which attempted to identify factors associated with sleep habits among school-age children in Turkey, found a significant association between their sleep habits and variables such as maternal educational level, paternal educational level, family structure, family income, chronic diseases, playing computer and dietary pattern.

In the present study, the participants' parents educational status affected the participants' sleep habits. Of the participants, those whose parents' education level was low had more sleep problems than did those whose parents' education level was high. In the literature, there are studies indicating that there is a relationship between educational status of parents and sleep problems (10-12). As parents' education level increases, so do their socioeconomic levels and awareness of their children's sleep health, which affects children's sleep health positively. In the present study, family structure and family income were the factors that affected the sleep habits of school age children. Of the participating children, those having a single-parent family had a higher mean CSHQ score than did those having a two-parent family. These children had more sleep problems. In a study of Troxel et al. (14), children having a single-parent family were reported to have more sleep problems than did children having a two-parent family. In single-parent families, the parent's having to take on more responsibility because of being alone (the other parent's responsibility is laid on him/ her too), and differences in parental control and family routines may cause children to have more sleep problems. In the present study, of the participants, those having families with low income had more sleep problems than did the others. In the literature, there are studies whose results are consistent with those of the present study $(40,41)$ On the other hand, in their study, Smaldone et al. reported that children in high-income families had more sleep problems.

Children with chronic diseases not only try to overcome the symptoms of the disease, but also suffer from physical, social, psychological, developmental and environmental problems due to their diseases. Having a chronic disease is among the factors leading to decreases in sleep time in children (25). In the present study, the mean CSHQ score of the children with a chronic disease was higher than was that of the children without a chronic disease, suggesting that they had more sleep problems. Studies have shown that sleep problems increase in children with chronic diseases (20-22). Chronic diseases can affect sleep due to symptoms getting worse at night, diseaserelated pain, hospitalization, side effects of drugs, etc.

In the present study, the children who played computer games
1 hour and more had more sleep problems than did those who played computer games less than 1 hour. In several studies, it was reported that there was a relationship between the duration of computer use and sleep problems and that spending more than 2 hours a day on the computer caused difficulty in falling asleep and waking up (15-18). In their systematic review and meta-analysis, Mei et al. (19) determined that overuse of computers (excessive computer usage) caused sleep problems. There are many studies indicating the effect of dietary habits on sleep problems in children. Several studies have demonstrated that there is a relationship between unhealthy eating habits and sleep habits, between the way food is consumed and sleep habits, and positive relationship between sleep duration and dietary habits including fruits and vegetables (6-8). Another finding indicates that while carbohydrate-based diet increases sleep time, fat-based diet reduces it (9). In the present study, it was found that of the participating children, those who were at high risk in terms of diet habits had more sleep problems.

\section{Conclusion}

In the present study, it was found that parents' education level, family structure, family income level, presence of a chronic disease, playing computer games and dietary habits affected the participants' sleeping habits. Of the participants, those who had parents with low levels of education, single-parent family, low family income and a chronic disease, who played computer games 1 hour and more per day and children and/or who were at high risk of inappropriate dietary habits had more sleep problems. It could be recommended that school nurses be more careful and questioning while evaluating the sleep characteristics of school-aged children. School nurses should also inform parents and children about sleep problems.

\section{Ethics}

Ethics Committee Approval: The study was approved by the Pamukkale University Ethics Committee (approval number: 60116787-020/3517).

Informed Consent: Written consent was obtained from the parents and children.

Peer-review: Internally peer-reviewed.

\section{Authorship Contributions}

Concept: F.H.İ,, N.K., I.Ö.Ç., G.K.A., A.K., Design: F.H.İ, N.K., I.Ö.Ç., G.K.A., A.K., Data Collection or Processing: F.H.I., N.K., I.Ö.Ç., G.K.A., A.K., Analysis or Interpretation: F.H.I.., Literature Search: F.H.I., N.K., İ.Ö.Ç., G.K.A., A.K., Writing: F.H.I., N.K.

Conflict of Interest: The authors declare no conflict of interest. Financial Disclosure: This study was supported by Scientific Research Coordination Unit of Pamukkale University under the project number 2016KKP151.

\section{References}

1. Amschler DH, McKenzie JF. Elementary students' sleep habits and teacher observations of sleep-related problems. J Sch Health 2005;75:50-6.

2. Jenni OG, O'Connor BB. Children's Sleep: An Interplay Between Culture and Biology. Pediatrics 2005;115:204-16. 
3. Owens J. Classification and Epidemiology of Childhood Sleep Disorders. Sleep Medicine Clinics 2007;2:533-46.

4. Chen X, Beydoun MA, Wang Y. Is Sleep Duration Associated With Childhood Obesity? A Systematic Review and Meta-analysis. Obesity 2008; 16:265-74.

5. Patel SR, Hu FB. Short sleep duration and weight gain: A systematic review. Obesity 2008;16:643-53.

6. Gaina A, Sekine M, Hamanishi S, Chen X, Wang H, Yamagami T, Kagamimori S. Daytime Sleepiness and Associated Factors in Japanese School Children. J Pediatr 2007;151:518-22.

7. Westerlund L, Ray C, Roos E. Associations between sleeping habits and food consumption patterns among 10-11-year-old children in Finland. Br J Nutr 2009;102:1531-7.

8. Moreira P, Santos S, Padrão P, Cordeiro T, Bessa M, Valente H, Baroos $\mathrm{R}$, Teixeira V, Mitchell V, Lopes C, Moreira A. Food patterns according to Sociodemographics, physical activity, sleeping and obesity in Portuguese children. Int J Environ Res Public Health 2010;7:1121-38.

9. Weiss A, Xu F, Storfer-Isser A, Thomas A, levers-Landis CE, Redline $S$. The association of sleep duration with adolescents' fat and carbohydrate consumption. Sleep 2010;33:1201-9.

10. Buckhalt JA, El-Sheikh M, Keller PS, Kelly RJ. Concurrent and longitudinal relations between children's sleep and cognitive functioning: The moderating role of parent education. Child Dev 2009;80:875-92.

11. Jalilolghadr S, Pakpour-Hajiagha A, Heidaralifard M, Pakzad R. Evaluation of sleep habits and sleep patterns among 7-12-year-old students in Qazvin, Iran; a school-based cross-sectional study. J Compr Pediatr 2018;9:e67189.

12. Kjeldsen JS, Hjorth MF, Andersen R, Michaelsen KF, Tetens I, Astrup A, Chaput J-P, Sjödin A. Short sleep duration and large variability in sleep duration are independently associated with dietary risk factors for obesity in Danish school children. Int J Obes 2014;38:32-9.

13. Owens JA, Jones C. Parental knowledge of healthy sleep in young children: Results of a primary care clinic survey. Journal of Developmental and Behavioral Pediatrics 2011;32:447-53.

14. Troxel WM, Lee L, Hall M, Matthews KA. Single-parent family structure and sleep problems in black and white adolescents. Sleep Med 2014;15:255-61.

15. Dworak M, Schierl T, Bruns T, Struder HK. Impact of Singular Excessive Computer Game and Television Exposure on Sleep Patterns and Memory Performance of School-aged Children. Pediatrics 2007;120(5):978-85.

16. Garmy P, Nyberg P, Jakobsson U. Sleep and Television and Computer Habits of Swedish School-Age Children. J Sch Nurs 2012;28:469-76.

17. Arora T, Broglia E, Thomas GN, Taheri S. Associations between specific technologies and adolescent sleep quantity, sleep quality, and parasomnias. Sleep Med 2014; 15:240-7.

18. Bartel KA, Gradisar M, Williamson P. Protective and risk factors for adolescent sleep: A meta-analytic review. Sleep Medicine Reviews 2015;21:72-85.

19. Mei X, Zhou Q, Li X, Jing P, Wang X, Hu Z. Sleep problems in excessive technology use among adolescent: a systemic review and meta-analysis. Sleep Sci Pract 2018;2:9.

20. Newman Cl, O'Regan $M$, Hensey O. Sleep disorders in children with cerebral palsy. Dev Med Child Neurol 2006;48:564-8.

21. Valrie CR, Gil KM, Redding-Lallinger R, Daeschner C. Brief report: Sleep in children with sickle cell disease: An analysis of daily diaries utilizing multilevel models. J Pediatr Psychol 2007;32:857-61.

22. Lopes MC, Guilleminault C, Rosa A, Passarelli C, Roizenblatt S, Tufik S. Delta sleep instability in children with chronic arthritis. Brazilian J Med Biol Res 2008;41:938-43.
23. Chen X, Beydoun MA, Wang Y. Is Sleep Duration Associated With Childhood Obesity? A Systematic Review and Meta-analysis. Obesity 2008; 16:265-74

24. Hirshkowitz M, Whiton K, Albert SM, Alessi C, Bruni O, DonCarlos L, Hazen N, Herman J, Katz ES, Kheirandish-Gozal L, Neubauer DN, O'Donnell AE, Ohayon M, Peever J, Rawding R, Sachdeva RC, Setters B, Vitiello M, Ware JC, Hillard PJA. National sleep foundation's sleep time duration recommendations: Methodology and results summary. Sleep Heal 2015;1:40-3.

25. American Academy of Pediatrics. American Academy of Pediatrics Supports Childhood Sleep Guidelines. [Internet]. 2016 [cited 2018 Nov 27]. Available from: https://www.aap.org/en-us/about-the-aap/ aap-press-room/pages/American-Academy-of-Pediatrics-SupportsChildhood-Sleep-Guidelines.aspx

26. Owens J, Adolescent Sleep Working Group and Committee on Adolescence. Insufficient Sleep in Adolescents and Young Adults: An Update on Causes and Consequences. Pediatrics 2014;134:e921-32.

27. Centers for Disease Control and Prevention. Defining childhood obesity [Internet]. 2009 [cited 2018 May 28]. Available from: https:// www.cdc.gov/obesity/childhood/defining.html

28. Demirezen E, Coşansu G. Evaluating dietary pattern in adolescence. STED 2005;14:174-8.

29. Owens JA, Spirito A, Mcguinn M. The Children's Sleep Habits Questionnaire (CSHQ): psychometric properties of a survey instrument for school-aged children. Sleep 2000;23:1043-51.

30. Fis NP, Arman A, Ay P, Topuzoglu A, Gueler AS, Imren SG, Ersu R, Berkem $M$. The validity and the reliability of Turkish Version of Children's Sleep Habits Questionnaire. Anatol J Psychiatry 2010;11:151-60.

31. Hatzinger Reinhold NH. PASW Statistics [Internet]. Chicago, IL: SPSS Inc. 2009. 1-384 p. Available from: http://scholar.google.com/ scholar?hl=en\&btnG=Search\&q=intitle:PASW+Statistics\#6

32. Canet T. Sleep-wake habits in Spanish primary school children. Sleep Med 2010;11:917-21.

33. Koçoğlu D, Kesgin M, Kulakçı H. The Influence of Sleep Habits and Sleep Problems on Some School Functions of Elementary School 2nd Level Students. Hacettepe Univ Fac Heal Sci Nurs J 2010;1 7:24-32.

34. Firouzi S, Poh BK, Ismail MN, Sadeghilar A. Sleep habits, food intake, and physical activity levels in normal and overweight and obese Malaysian children. Obes Res Clin Pract 2014;8:e70-8.

35. Bharti B, Malhi P, Kashyap S. Patterns and problems of sleep in school going children. Indian Pediatr 2006;43:35-8.

36. Park S. The Association Between Short Sleep Duration and Body Mass Index Among South Korean Children and Adolescents. J Sch Nurs 2013;29:142-50.

37. Li S, Zhu S, Jin X, Yan C, Wu S, Jiang F, Shen X. Risk factors associated with short sleep duration among Chinese school-aged children. Sleep Med 2010;11:907-16.

38. Shur-Fen Gau S. Prevalence of sleep problems and their association with inattention/hyperactivity among children aged 6-15 in Taiwan. J Sleep Res 2006;15:403-14.

39. Surani $S$, Hesselbacher S, Surani S, Sadasiva S, Surani Z, Surani SS, Khimani A, Subramanian S. Sleep Habits of Elementary and Middle School Children in South Texas. Sleep Disord 2015;2015:1-9.

40. Jarrin DC, McGrath JJ, Quon EC. Objective and subjective socioeconomic gradients exist for sleep in children and adolescents. Heal Psychol 2014;33:301-5.

41. Smaldone A, Honig JC, Byrne MW. Sleepless in America: Inadequate Sleep and Relationships to Health and Well-being of Our Nation's Children. Pediatrics 2007;119(Suppl 1):29-37. 